\title{
Catalytic Reactions: Determination of Trace Amounts of Copper in Natural Samples
}

\author{
Wilson F. Jardim and Jarbas J. R. Rohwedder \\ Instituto de Química, Universidade Estadual de Campinas, CP 6154, 13100 Campinas, SP, Brazil
}

\begin{abstract}
Under alkaline conditions, copper(II) ions catalyse the oxidation of hydroxylamine to nitrite. This catalytic reaction allows the determination of trace amounts of copper in natural samples. The mechanism of oxidation relies on superoxide ions generated from dissolved oxygen. For tap water and lake water samples, the results obtained indicated satisfactory levels of precision and accuracy.
\end{abstract}

Keywords: Catalytic reactions; copper determination; natural samples

\begin{abstract}
The determination of trace concentrations of some metals in aquatic systems has become an important factor because of the toxic effects they may have on living organisms. As the metal concentration in natural aquatic samples (i.e., rivers, lakes and tap water) is usually low, sensitive analytical techniques are required. Voltammetry, atomic absorption and catalytic reactions are examples of suitable techniques that can be used in the determination of trace metals. However, whereas voltammetry and atomic absorption may require technical support to operate the equipment and have a high cost per sample, catalytic reactions involve simple, rapid and low cost spectrophotometric measurements.
\end{abstract}

Over the past decade, the use of catalytic reactions in trace analysis has developed substantially. ${ }^{1}$ Although the technique often has poor selectivity and a high level of interfering species, sensitivity is very high.

The determination of copper in blood serum has been carried out by following its catalytic effects on the reduction of iron(III) salts with thiosulphate. ${ }^{2}$ Heller and Guyon ${ }^{3}$ used a method based on the ascorbic acid reduction of the isopolymolybdate ion in the presence of minute amounts of copper. More recently, Nakano et al. ${ }^{4}$ determined nanogram levels of copper by the oxidative coupling reaction of $N$-phenyl-pphenylenediamine with $N, N$-dimethylaniline.

In this work, a very simple and sensitive method for determining copper is presented. Under alkaline conditions, trace amounts of copper catalyse the oxidation of hydroxylamine to nitrate ions. After a suitable period of time (up to 120 $\mathrm{min})$, the resulting nitrite concentration is then determined spectrophotometrically as a strongly coloured azo compound.

\section{Experimental}

\section{Reagents}

To avoid highly coloured blank values, de-ionised, doubly distilled water was used throughout. Glassware was cleaned by soaking in $10 \% \mathrm{~V} / \mathrm{V}$ nitric acid overnight.

Buffer solution. To prepare a $0.01 \mathrm{M}$ sodium tetraborate buffer solution, $3.81 \mathrm{~g}$ of sodium tetraborate $\left(\mathrm{Na}_{2-}\right.$ $\mathrm{B}_{4} \mathrm{O}_{7} \cdot 10 \mathrm{H}_{2} \mathrm{O}$ ) were dissolved in 11 of water. The final $\mathrm{pH}$ was 9.18 .

Hydroxylamine solution. To prepare a $0.1 \mathrm{~m}$ solution, $1.74 \mathrm{~g}$ of hydroxylamine hydrochloride were dissolved in $250 \mathrm{ml}$ of water.

Mixed nitrite reagent. In a 11 calibrated flask, $5.00 \mathrm{~g}$ of sulphanilic acid $\left\{\left[4-\left(\mathrm{H}_{2} \mathrm{~N}\right) \mathrm{C}_{6} \mathrm{H}_{4} \mathrm{SO}_{3} \mathrm{H} . \mathrm{H}_{2} \mathrm{O}\right]\right\}$ were dissolved in a mixture of $750 \mathrm{ml}$ of water and $35 \mathrm{ml}$ of $1 \mathrm{M}$ hydrochloric acid. The solution was heated and, after cooling to room temperature, $25 \mathrm{ml}$ of a $20 \% \mathrm{~m} / \mathrm{V}$ solution of $\mathrm{N}$-(1naphthyl)ethylenediamine dihydrochloride $\left(\mathrm{C}_{10} \mathrm{H}_{7} \mathrm{NHCH}_{2}-\right.$ $\mathrm{CH}_{2} .2 \mathrm{HCl}$ ) were added. The final volume was adjusted to $1 \mathrm{l}$.

\section{Effects of pH}

The generation of nitrite as a function of $\left[\mathrm{OH}^{-}\right]$is shown in Fig. 1. In the presence of sodium tetraborate buffer, the production of nitrite was greatly enhanced. As the generation of nitrite follows a first-order reaction with respect to the concentration of hydroxyl ions, it was decided to work at a buffered $\mathrm{pH}$ of 9.18 (sodium tetraborate). At $\mathrm{pH}$ values above 10 , any minor variation in this parameter will be reflected as larger variations in the absorbance readings.

\section{$\mathrm{NH}_{2} \mathrm{OH}$ Concentration}

Fig. 2 shows the production of nitrite as a function of different concentrations of hydroxylamine. For both $1 \times 10^{-7}$ and $5 \times$ $10^{-7} \mathrm{M}$ solutions of copper(II), nitrite generation increased as the concentration of $\mathrm{NH}_{2} \mathrm{OH}$ increased, reaching a constant value above $10^{-3} \mathrm{M}$ of hydroxylamine.

\section{Procedure}

Determination of copper in tap water

To a $10-\mathrm{ml}$ sample in a test tube, $5 \mathrm{ml}$ of the sodium tetraborate buffer solution and $0.3 \mathrm{ml}$ of the hydroxylamine solution were added. After a suitable period of time,

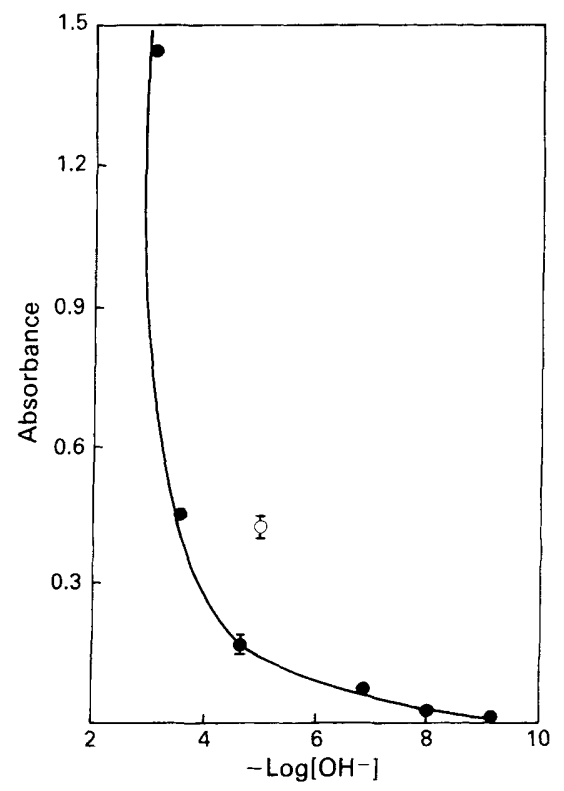

Fig. 1. Generation of nitrite as a function of $\left[\mathrm{OH}^{-}\right]$. The effect caused by the presence of sodium tetraborate buffer $\left(1 \times 10^{-2} \mathrm{M}\right)$ is also shown (O). Total copper concentration, $1 \times 10^{-7} \mathrm{M}$ 


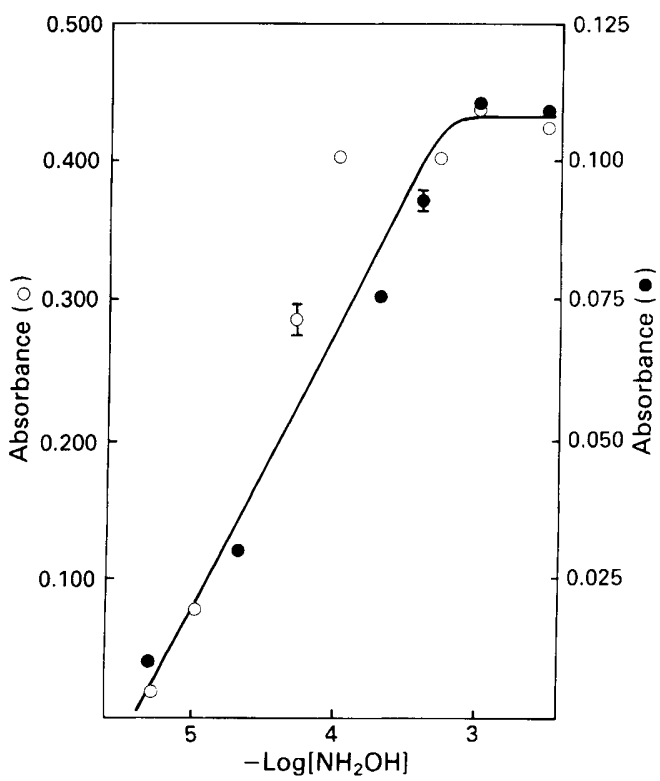

Fig. 2. Generation of nitrite as a function of the concentration of the hydroxylamine in copper solutions. Copper concentration: $0,1 \times$ $10^{-7} \mathrm{M}$; and $\mathrm{O}, 5 \times 10^{-7} \mathrm{M}$

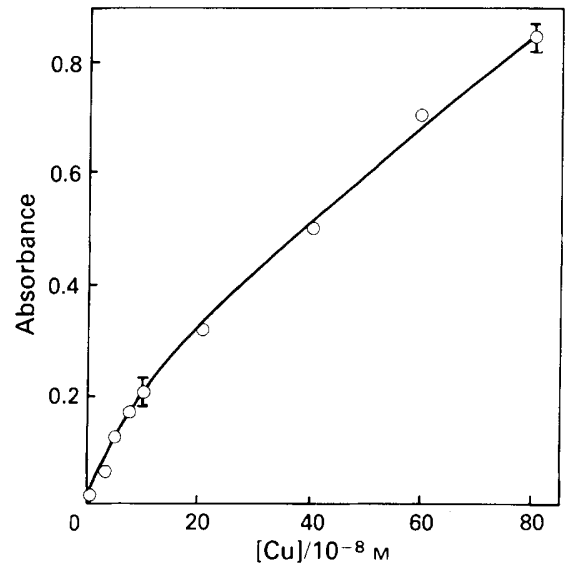

Fig. 3. Calibration graph for $1-80 \times 10^{-8} \mathrm{M}$ copper

Table 1. Copper concentration in natural samples*

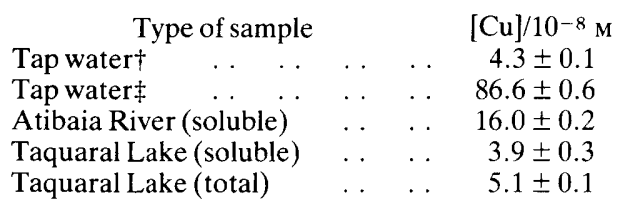

* Results are the mean \pm standard deviation of five replicates.

† First $500 \mathrm{ml}$ sampled after $12 \mathrm{~h}$ standing in the pipe.

$\ddagger$ First $500 \mathrm{ml}$ sampled after $48 \mathrm{~h}$ standing in the pipe.

measurable amounts of nitrite were generated. Usually, at the concentration levels found in tap water (between $10^{-8}$ and $\left.10^{-7} \mathrm{M}\right), 90 \mathrm{~min}$ were sufficient. For the nitrite determination, $5 \mathrm{ml}$ of the mixed nitrite reagent were added to the buffered solution and the absorbance was measured at $540 \mathrm{~nm}$ after 30 min. The final copper concentration was calculated by either comparing the results with a calibration graph (Fig. 3), or by using the standard additions approach.

\section{Determination of copper in superficial waters}

The method was also applied to superficial water samples. As naturally occurring ligands interfere owing to the complexation of copper(II) ions, speciation studies could also be performed.

For the determination of the soluble copper concentration, after filtering the water sample using a $0.45 \mu \mathrm{m}$ membrane, 10 $\mathrm{ml}$ of the filtrate were treated as in the procedure for tap water analysis. For the determination of the total copper concentration, the water sample was digested prior to the analysis. An effective digestion was carried out by adding $5 \mathrm{ml}$ of concentrated $\mathrm{HNO}_{3}$ to $50 \mathrm{ml}$ of water sample. The sample was evaporated until fumes appeared and the residues were dissolved to give the original volume.

\section{Results and Discussion}

The technique described above has been applied to a wide variety of natural and synthetic samples in our laboratory. Some of the results are given in Table 1 .

The major interfering cations were found to be Fe(III) and $\mathrm{Co}(\mathrm{II})$. Both metals inhibited the generation of nitrite when present at concentrations above $10^{-6} \mathrm{M}$ for a total copper concentration of $10^{-7} \mathrm{M}$. Phosphate and hydrogen peroxide also interfered in the determination of copper when present in the sample at concentrations above $10^{-5} \mathrm{M}$. The interference caused by nickel, cadmium, silver, zinc and Mn(IV) were found to be negligible up to a concentration of $10^{-4} \mathrm{M}$ for a total copper concentration of $10^{-6} \mathrm{M}$.

Although many aspects concerning the catalytic behaviour of metals such as copper have yet to be clarified, Hughes and Nicklin ${ }^{5}$ have discussed a possible pathway to explain the generation of nitrite. They suggested the formation of peroxynitrite ions via the nitroxyl ion:

$$
\begin{array}{ccc}
\mathrm{NH}_{2} \mathrm{O}^{-}+\mathrm{O}_{2} \rightleftharpoons \mathrm{H}_{2} \mathrm{O}_{2}+\mathrm{NO}^{-} & \ldots & \ldots \\
\mathrm{NO}^{-}+\mathrm{O}_{2} \rightleftharpoons \mathrm{ONOO}^{-} & \ldots & \ldots
\end{array}
$$

which produces nitrite in a copper-catalysed reaction:

$$
\mathrm{ONOO}^{-}+\mathrm{NH}_{2} \mathrm{O}^{-} \stackrel{\mathrm{Cu}^{2+}}{\rightleftharpoons} \mathrm{NO}_{2}^{-}+\mathrm{NO}^{-}+\mathrm{H}_{2} \mathrm{O} \text {. . }
$$

However, it was found in this work that the mechanism involved the generation of superoxide ions via dissolved oxygen. Indeed, in either de-aerated samples or in samples containing the enzyme superoxide dismutase, the production of nitrite is negligible. The superoxide would then be responsible for the oxidation of hydroxylamine to nitrite.

The accuracy of this technique was tested by comparing the results obtained with those found on measuring the copper concentration in tap water by differential-pulse anodic stripping voltammetry (DPASV). Using DPASV, the total copper concentration found was $(4.94 \pm 0.60) \times 10^{-7} \mathrm{M}$, whereas using the catalytic reaction, the value obtained was $(4.30 \pm$ $0.10) \times 10^{-7} \mathrm{M}(n=4)$.

\section{References}

1. Milovanovic, G. A., Microchem. J., 1983, 28, 437.

2. Khalifa, K., Doss, H., and Awadallah, R., Analyst, 1970, 95, 207.

3. Heller, R. L., Jr., and Guyon, J. C., Anal. Chem., 1968, 40, 773.

4. Nakano, S., Tanaka, M., Fushihara, M., and Kawashima, T., Mikrochim. Acta, 1983, I, 457.

5. Hughes, M. N., and Nicklin, H. G., J. Chem. Soc. A, 1974, 164.

Paper A5/313

Received September 9th, 1985 Accepted January 22nd, 1986 